\title{
Relationship Between Educational Level of Students' Parent with Students Achievement at Elementary School
}

\author{
Fatmah Djumuli $^{1}$ Isnanto $^{2}$ \\ Universitas Negeri Gorontalo, Gorontalo, Indonesia
}

e-mail: fatmahdjumuli@gmail.com

\begin{abstract}
The purpose of the research was to know the relationship between educational level of students' parent with students Achievement. The research was conducted by using ex post facto with correlation method. This study involved 8 elementary schools at Kecamatan Bulango Kabupaten Bone Bolango - Gorontalo. The data were shown that value of $x^{2}$ count $=30,832$ in and $\mathrm{df}=6$, value of $=12,591$. So, it can be concluded that it has Relationship between the educational level of students' parent with students Achievement.
\end{abstract}

Keywords: Educational level, students' parent, student achievement

\section{INTRODUCTION}

Parents educational level have an effect on student achievement. Parents who have a high educational level, sometimes give their attention to their children to learn more. But sometimes parents who have a high educational level also have a good occupation, so they have no time to guide their children to learn at home. The opposite, parents who have low levels of education and have a job such as a farmer or fisherman have many times at home so they can spend time by guide or ask their children to study or learn at home.

The other side, parents who have high level have a way to make their children to get good achievement through informal education (tuition) after the formal class at school. But parents who have a job as a farmer or fisherman have no much money to register their children to informal education, and it makes their children have no achievement at school.

These two phenomena, can make students have a good or bad achievement, whether students from a farmer or fisherman. So, this article explains about the "Relationship Between Educational Level of Students' Parent With Students Achievement at Elementary School".

According to Tohirin opinion, student achievement is what the students get after the their learning process in the class (Setiawan, 2015: 12). In more opinion, Setiawan (2015: 2) also said that: the student achievement in a subject will appear after the learning evaluation and measurement process of learning result.

Learning achievement is a perennial problem in human history, because human always chasing achievement base on their field and their expert (Arifin, 2013:12).

Reskia, et.al (2014: 86) said that parents are a figure to form children personality. It hopes to give direction, controlling, guide children development

The Parent who has higher education also has more confidence to help their children to learn. By the level of believing, it assume will have a significancy effect on their children in academic ability (Reskia, et.al., 2014: 86).

In around family area, parent have participation as an educator (father and mother). Parent is first and main educator to help in improving the child's potential. They were said as the first educator because they give first education since they born. They were said as a main educator because the education what give by parent is a basic and very determine child development to the next (Sakdiyah, 2011:39). 


\section{METHODS}

The research was conducted in elementary school around Sub-District of Bulango Utara, District of Bone Bolango, Gorontalo Province. It was consisted of 8 schools. The research was used correlation method. Data were collected by documentation, questionnaire. Data was analyzed by using descriptive statistic and inferential statistic in non-parametric statistic form

\section{RESULT AND DISCUSSION}

Data was collected from 60 students at grade $\mathrm{V}$ all elementary at sub-district of Bulango Utara, as shown in the diagram below:

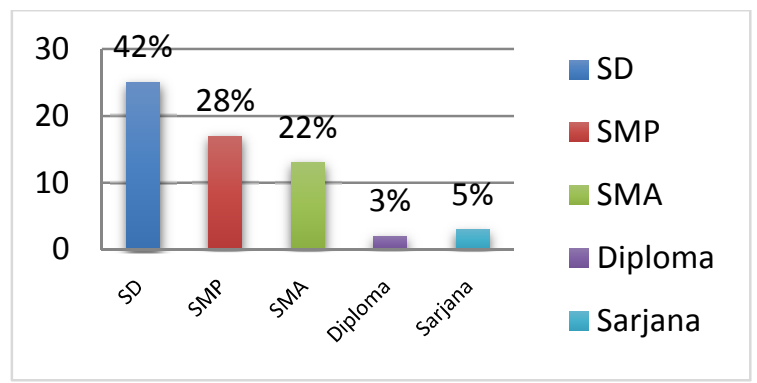

Figure 1.Students' parent educational level

Table 1. Variable description

\begin{tabular}{|c|c|c|c|c|}
\hline Variable & Average & Variance & Minimum & Maximum \\
\hline $\begin{array}{c}\text { Students } \\
\text { Learning } \\
\text { Result }\end{array}$ & 81,25 & 20,88 & 70 & 90 \\
\hline
\end{tabular}

Based on the above table can provide information about the average achievement of learners in class V State Elementary School as District Bulango Utara is 81.25 with a minimum value of 70 and the maximum value is 90 . It is able to provide information learners class $\mathrm{V}$ State Elementary School in North Bulango District can reach the highest value of 90 is still there that produces 70 .

Frequency distribution of student achievement in table 2.

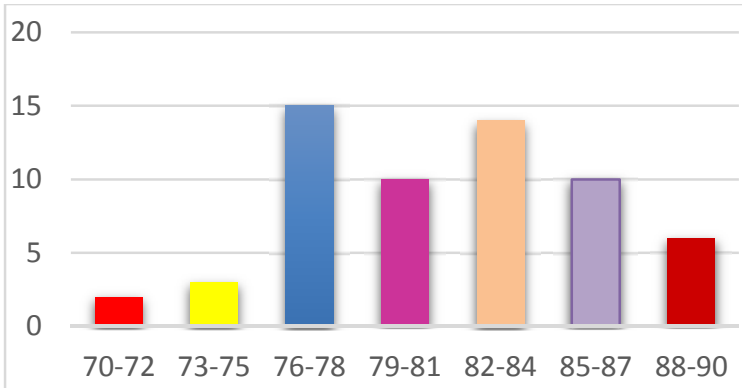

Figure 2. Histogram of Students Achievement

Table 3 achievement of student achievement and table 4 student achievement values below.

After calculating the value of hope, now continue to calculate chi-square value. Value of chisquare $\chi_{\text {hit }}^{2}=30,832$. For significant level $\alpha=0.05$ and degree of freedom 6 , the value was $\chi_{\text {tabel }}^{2}=12,591$. So can be concluded that hypothesis $H_{0}$ refuse because. It meant that have a relationship between level of parent education and student achievement.

Meanwhile, value of coefficient contingency was 0,582 and values of $C_{\text {max }}$ were 0,80 .

\subsection{Discussion}

The result of data analysis by using coefficients contingency $=0,582$ and $C_{\max }=0,80$. So, $\mathrm{H}_{0}$ was refused and $\mathrm{H}_{\mathrm{a}}$ was accepted. And it can be concluded that: have a relationship between level of students' parents and student achievement at grade $\mathrm{V}$ in all elementary schools in sub-district of Bulango Utara, Bone Bolango District

Based on the result of data analysis, the level of parents' education has a positive factor in student achievement. Parents educational level in high position will give motivation to the children's achievement. While, low level of parents' education cause student achievement result not satisfied (low standard).

So that, high or low student achievement correlated with parents' educational level. Parents ought to guide their children at home in order to motivate to learn intensively, not only depend by the 
teacher at school. Parents not only give material need, but also they must give educational need.

As those all above has to be recited as: have a negative relationship between level of students' parents and student achievement at grade $\mathrm{V}$ in all elementary schools in sub-district of Bulango Utara, Bone Bolango District, because result research shown that lower level of students' parents, higher in students achievement. And the higher level of students' parents, low in students' achievement.

\section{CONCLUSION AND RECOMMENDATION}

Research conclusion:

1. Student achievement at all elementary schools in Bulango Utara sub-district average $=81,25$ with minimal score $=70$ and maximal score $=$ 90. It meant student achievement in good categories.

2. Has a negative relationship between level of students' parents and student achievement at grade $\mathrm{V}$ in all elementary schools in subdistrict of Bulango Utara, Bone Bolango District.

Research Recommendation:

Based result research and discussion that have a negative relationship between level of students' parents and student achievement at grade $\mathrm{V}$ in all elementary schools in sub-district of Bulango Utara, Bone Bolango District, so parents must give motivation by giving suggestions and controlling their children at home.

\section{REFERENCE}

[1] Arifin, Zainal. 2013. Evaluasi Pembelajaran. Bandung. Remaja Rosdakarya.

[2] Aziz, Safrudin. 2015. Pendidikan Keluarga. Yogyakarta: Gava Media.

[3] Baharuddin. dan Wahyuni, Esa Nur. 2015. Teori Belajar dan Pembelajaran. Yogyakarta: Ar- Ruzz Media.

[4] Barnadib, Sutari Imam. 2013. Pengantar Ilmu Pendidikan Sistematis. Yogyakarta: Ombak.

[5] Djamarah, Syaiful Bahri dan Zfain, Aswan. 2010. Strategi Belajar Mengajar. Jakarta: Rineka Cipta

[6] Emzir. 2015. Metodologi Penelitian Pendidikan. Jakarta: RajaGrafindo Persada.

[7] Hamdayana, Jumanta. 2016. Metodologi Pengajaran. Jakarta: Bumi Aksara.
[8] Hadi, Sutrisno. 2015. Statistik. Yogyakarta. Pustaka Pelajar.

[9] Hisbanarto, Yakub Vico. 2014. Sistem Informasi Manajemen Pendidikan. Yogyakarta: Graha Ilmu.

[10] Maliki, Zainuddin. 2010. Sosiologi Pendidikan. Yogyakarta: Gajah Mada University Press

[11] Mudyahardjo, Redja. 2008. Filsafat Ilmu Pendidikan. Bandung: Remaja Rosdakarya Offset.

[12] Nasution. 2010. Berbagai Pendekatan Dalam Proses Balajar Dan Mengajar. Jakarta: Bumi Aksara.

[13] Nugroho, Riant. 2008. Kebijakan Pendidikan yang Unggul. Yogyakarta: Pustaka Pelajar.

[14] Purwanto, Ngalim. 2009. Ilmu Pendidikan Teoritis Dan Praktis. Bandung : Remaja Rosdakarya.

[15] Rahmat, Abdul. 2015. Belajar dan Pembelajaran. Kota Gorontaalo : Ideas Publishing.

[16] Rahmat, Abdul. 2014. Pengantar Pendidikan. Gorontalo: Ideas Publishing.

[17] Rohman, Arif. 2010 . Pendidikan Komparatif . Yogyakarta: Laksbang Grafika.

[18] Rusman . 2013. Model-Model Pembelajaran . Jakarta: Rajagrafindo Persada.

[19] Sagala,Syaiful. 2008. Administrasi Pendidikan Kontemporer. Bandung: ALVABETA.

[20] Semiawan, Conny. 2008. Belajar dan Pembelajaran Prasekolah dan Sekolah Dasar. Jakarta. Indeks.

[21] Suprijono, Agus. 2012. Cooperative Learning Teori dan Aplikasi PALKEM. Yogyakarta: Pustaka Pelajar.

[22] Sudijono, Anas. 2015. Pengantar Evaluasi Pendidikan. Jakarta. Raja Grafindo Persada

[23] Wibowo, Agus. 2013. Akuntabilitas Pendidikan. Yogyakarta: Pustaka Pelajar.

[24] Reskia,Sri.Herlina.Zulnuraini.2014.

Elementary School of Education E-Journal 82 Diterbitkan online PGSD, FKIP, Universitas Tadulako Elementary School of Education EJournal, Media Publikasi Ilmiah Prodi PGSD http://jurnal.untad.ac.id/jurnal/index.php/ESE Diakses Kamis 9 Juni 2015 (19:15)

[25] Sakdiyah,Siti.2011. Pengaruh Tingkat Pendidikan Orang Tua Terhadap Prestasi Belajar Anak Di Sekolah (Studi Pada Kelas VI II Di Madrasah Tsanawiyah Negeri Klego Kabupaten Boyolali Tahun 2011/2012). 
STAIN.Salatigahttp://perpus.iainsalatiga.ac.id/ docfiles/fulltext/63519de510891598.pdf Diakses kamis 9 Juni 2015 (19:15)

[26] Setiawan, Arif Yuhdi. (2015) Pengaruh Tingkat Pendidikan Orang Tua Dan Disiplin Belajar Siswa Terhadap Prestasi Belajar Akuntansi Siswa Kelas XI Ips Sma Negeri 1 Pakem Tahun Ajaran 2013/2014. UNY. http://eprints.uny.ac.id/14875/1/SKRIPSI.pdf Diakses kamis 9 Juni 2015 
Table 2. Distribution of Frecuency Students Achievement

\begin{tabular}{|c|c|r|c|r|c|c|r|r|}
\hline No & Interval Class & \multicolumn{1}{c|}{$F_{i}$} & $x_{i}$ & $F_{i}^{*} x_{i}$ & $d$ & $d^{2}$ & $F_{i}^{*} \mathrm{~d}$ & $F_{i}^{*}(\mathrm{~d})^{2}$ \\
\hline 1 & $70-72$ & 2 & 71 & 142 & -3 & 9 & -6 & 18 \\
\hline 2 & $73-75$ & 3 & 74 & 222 & -2 & 4 & -6 & 12 \\
\hline 3 & $76-78$ & 15 & 77 & 1155 & -1 & 1 & -15 & 15 \\
\hline 4 & $79-81$ & 10 & 80 & 800 & 0 & 0 & 0 & 0 \\
\hline 5 & $82-84$ & 14 & 83 & 1162 & 1 & 1 & 14 & 14 \\
\hline 6 & $85-87$ & 10 & 86 & 860 & 2 & 4 & 20 & 40 \\
\hline 7 & $88-90$ & 6 & 89 & 534 & 3 & 9 & 18 & 54 \\
\hline & Total & 60 & & 4875 & & 28 & 25 & 153 \\
\hline
\end{tabular}

Table 3. Contingency Students Achievement

\begin{tabular}{|c|c|c|c|c|c|c|c|c|}
\hline $\begin{array}{c}\text { Level of parents' } \\
\text { students }\end{array}$ & \multicolumn{7}{|c|}{ Students' Achievement } & \multirow{2}{*}{ Total } \\
\cline { 2 - 9 } & $70-72$ & $73-75$ & $76-78$ & $79-81$ & $82-84$ & $85-87$ & $88-90$ & 25 \\
\hline SD & 1 & 2 & 9 & 1 & 7 & 3 & 2 & 25 \\
\hline SMP & 1 & 0 & 3 & 5 & 4 & 5 & 1 & 19 \\
\hline SMA & 0 & 0 & 2 & 4 & 2 & 2 & 1 & 11 \\
\hline D1. D2. D3 or D4 & 0 & 0 & 2 & 0 & 0 & 0 & 0 & 2 \\
\hline S1. S2 or S3 & 0 & 0 & 0 & 0 & 1 & 0 & 2 & 3 \\
\hline Total & 2 & 2 & 16 & 10 & 14 & 10 & 6 & 60 \\
\hline
\end{tabular}

Table 4. Value of Student Achievement Hope

\begin{tabular}{|c|c|c|c|c|c|}
\hline Observation & Value of Hope & Observation & Value of Hope & Observation & Value of Hope \\
\hline 1 & 0.833 & 5 & 3.167 & 0 & 0.333 \\
\hline 2 & 0.833 & 1 & 1.900 & 0 & 0.467 \\
\hline 9 & 6.667 & 0 & 0.367 & 0 & 0.333 \\
\hline 1 & 4.167 & 0 & 0.367 & 0 & 0.200 \\
\hline 7 & 5.833 & 2 & 2.933 & 0 & 0.100 \\
\hline 3 & 4.167 & 4 & 1.833 & 0 & 0.100 \\
\hline 2 & 2.500 & 2 & 2.567 & 0 & 0.800 \\
\hline 1 & 0.633 & 2 & 1.833 & 0 & 0.500 \\
\hline 0 & 0.633 & 1 & 1.100 & 1 & 0.700 \\
\hline 3 & 5.067 & 0 & 0.067 & 0 & 0.500 \\
\hline 5 & 3.167 & 0 & 0.067 & 2 & 0.300 \\
\hline 4 & 4.433 & 2 & 0.533 & & \\
\hline
\end{tabular}


